Стана Смиљковић

Учитељски факултет, Врање
371.3:: 821.09-343:398

https://doi.org/10.18485/filkult.2016.2.ch4

\title{
СИМБОЛИЧКИ ЈЕЗИК БАЈКИ
}

\section{Сажетак}

У овом раду истаћи ћемо функцију симбола којима се аутори служе при тумачењу ликова, њихових снова и догађаја који предстоје. Њима се проширује текст бајке, успоставља чудесна линија којом се јунаци крећу на путу остварења циља. Вишезначношћу симбола открива се својеврсна мудрост ликова, митолошка, филозофска и религиозна нит у бајци. На тај начин проширује се видно поље лика у бајкама, чиме се лик развија укључујући се у акције и драмске сукобе. Овај феномен илустроваћемо примерима бајки најпознатијих српских и европских аутора.

Кључне речи: симболи, језик, бајка, ликови, савремени, аутор, вишезначност, чудесност.

Симболи као имагинарни кључеви за отварање недостижних и недокучивих простора, омогућавају откривање специфичне бајковите наративности, лирског говора јунака и дијалога који доприносе драматичности. На тај начин оживљавају се слике светова, актери дефилују текстом бајке, а симболи остају као универзални вербални или писани знаци којима се може уобличити или разобличити стварност. Симболичне слике покрећу мисао, подстичу интелектуални напор, што значи да је симбол жив са пуноћом свога значења. Писац Мирче Елијаде истиче: „Симбол омогућава кретање кроз све нивое стварности." Може се рећи да симболи повезују делове космоса и указују на то да је човек јединка и његов део истовремено. Путем симболичних веза отварују се недостижни и недокучиви простори. Уз то треба додати енергију, претходна искуства која су стечена из различитих извора сазнања која се укрштају, преплићу, позајмљују, повезују или кидају да би се на крају спојила. 
У бајкама приказани говори, који могу бити научени или стечени, откривају њихове духовне светове, испољавају на тај начин светлости и мракове душе, загонетност појава. Као примере можемо навести бајке Десанке Максимовић, Бранка Ћопића, Луиса Керола и других. Иза свега описаног и казаног у бајкама ових писаца проширује се слика фантазије реалног света и живота која је проистекла из доживљајне свести писца. Опште теме о којима пишу остварују се кроз раскошне слике специфичном језичком визуелношћу при чему симболи заузимају значајно место.

Поједине сцене из бајковите наративности, посебном синтаксичко-лексичком структуром, претачу се у поетску драматичност. Такав је случај у роману Мали принц А. Егзиперија, Велики принц Данка Васовића, Гроздане Олујић, Андерсена. Срећу се и нижу симболи: лисице, руже, звезде, бројеви, слова, небо, месечева путања, ватра, звукови, небеске реке... Ако се говори о симболу ватре, издвојиће се, по снази и посебној бајковитој мудрости која проистиче из исказаних и предсказаних садржаја, бајка Девојчица са жижицама Андерсена. Симбол ватре и симбол неба представљају лични доживљај стварности главне јунакиње који прелази у општи одласком на онај свет. У овој бајци коју узимамо као пример, симболи се нижу у мислима девојчица, мисао се развија, богати се њена духовна природа, роје се мисли, оживљавају се могуће и немогуће слике. Паралелно са динамиком развоја радње, тече динамика дечје метаморфозе свести која продужава живот на небу. Способност писца да низом симбола створи слику живота (реалног) и паралелно, слику душе паћеника (девојчице), више је од фантазије. Прераста у чудо које се може разградити и надоградити; превести на реалност која је општеприхваћена и одвести у сфере имагинарног. Борба и драматика садржане у бити или не бити, одводи актера радње себи. Окретање себи, по Андерсену, најбољи је кутак јер је у њему јунак сам и свој. Сав свет је у његовој свести, дечјој, али нагомиланој искуством. Негативним, јер је свест изолована, ум осамљен. Не налази решење, налази га други. Крај бајке, антибајке, садржи тзв. трансформативну динамичност која ствара могућности разноврсне рецепције. Остварена је књижевна визија времена које траје и шаље поруке с неба. Слика сна која се девојчици јавља и лик умрле баке симболизује истински одлазак из реалности. Остварен је спој неба и земље. Чврсто их држи невидљива усправна линија. 
У бајкама поменутих аутора симболи представљају имагинарно гнездо у које се рађају креације. Њима се откривају тајне природе и постојања, као и људи. Зато у овој књижевној врсти као чудесносимболичној творевини - снови, жеље, идеје, мисли које могу бити свесне или несвесне - дефилују са јунацима. У том случају симболи се откривају или сакривају посебном техником приповедања и слагања делова у целину. Нарочито када су у питању супротности које кроз акције актера, кроз борбу између духовног - свесног и инстинктивног -несвесног чине да се успостави хармонија у свету и човеку.

Снага и ниво свести актера у бајци варира и зависи од многих фактора (времена, начина живота, простора, језика) и никада се та различитост не може докучити, нити језиком објаснити. Узмимо као пример Пушкинове бајке. У Бајци о рибару и рибици, бака се не задовољава положајем. Стање у коме се налази прождире људскост и преображава је у зло. Корито и колиба као симболи сиромаштва не ишчезавају, напротив, стално опомињу на реално стање. Двојна природа лика у овој и другим бајкама услов је за драмску тензију. Кроз акције којима се открива психологија баке успоставља се семантичка етикета лика: набој расте, да би на крају спласнуло све и отишло са персонифицираним ликом златне рибице. Пропињање морских таласа симболизује немир природе изазваним незаситом људском природом. Ћутање рибе, љутито запљускивање репом открива њено незадовољство поретком у људској природи.

Симболи као што су: обала, река, дрво, песак, планина, кола, белина рађају асоцијације које нас уводе у свет који живи на ивици маштовите реалности. У бајци Тадија Стевана Раичковића, спојем више животних доба и филозофије саткане од позитивних животних клица исказаних на концу када се животна искра гаси, није само појединачни симбол, већ универзална слика развоја и нестанка. Белина обезбеђује мир у вечности са халуцинантним звуком звона са прапораца. Сан је тако потпун и безграничан. Звук, слика, ретроспективно враћање незаборавним тренуцима уживања у животу - знак је да је човек само једна јединствена искра у хаотичном свету. У овој и другим бајкама симболима се спаја неспојиво: време, свест, простор, и све осим језичких виртуозности које се манифестују симболима.

У бајкама срећемо реалне и симболичне преображаје јунака и њихових мисли. Конкретно стреми духовном, а затим универзуму. 
Раичковићева бајка о дрвеним луткама које резбари жена Татага претварају се најпре у насмејана лица деце која се са смехом и кикотом удаљавају и одлазе у небо. Проширена симболично-метафорична слика означава непревазиђену лепоту рођену из дубине душе и срца.

Многе светлости имају вишеструку симболику у бајкама, а допиру одасвуд: са звезда, са месеца, пружају се са сунчеве дуге, јављају се у виду зрака који се шири, у виду белине, млечне магле, росе, сјаја у трави, светлости из очију јунака, из царских одаја и ковчежића, са дна неких подземних ходника, са истока, из густиша... То су симболичине светлости које јунаке воде циљу. Те светлости омогућавају писцима да створе чудесне игре које су искључиво плод духа, да обоје и осенче, ишарају и изломе сенке, да огреју душу и потхране мисао. Светлости се одбијају и од изрезбарених тањира и шара које је изрезбарио хендикепирани дечак, и од бисерја извезеног златном разнобојном свилом, и од дрвених лица лутки које уз помоћ тајанствене светлости одлазе у небо, од лица Малог принца које је даровано двојаком светлошћу: са звезда и са дна бунара у пустињи. Све те светлости остварују поетско-симболичну функцију простора и времена.

Оно што фантастично-симболичне слике не могу изаткати, изаткаће најфинији снови јунака. Снова је различитих, са њима и у њима се живи, постоји, тугује, пати, бори. Снови у бајкама су духовни, неухватни дамари који јунаке бајки чине сложенијим. У сновима се боре: живот и смрт, мржња и љубав, светлост и тама. Кроз сан се путује у поетично симболичан свет који нуди необична сазнања. Као најбољи пример може се узети Алиса у земљи чуда Луиса Керола. Звуци и покрети невидљиви голом оку и чујни онима који их снагом душе осете. Тако у бајкама Десанке Максимовић, Х. К. Андерсена, Егзиперија и других бајкописаца јунаци успостављају дијалектику мисли, времена и простора. Најмаркантнији је Мали принц који израста из симбола и симболима се враћа. Јавља се са звездама, одлази звездама и са смехом. Стремљење висини и пространству симболизује ширину света која се не замишља само географски. Лепше је духовно, мисаоно проширити слободу човека и његову жељу да избрише друмске и ваздушне границе. „Право испред себе далеко се не стиже“ - каже Мали принц. Мали принц није везан искључиво за планету Земљу. Жели сусрете са појавама и живим бићима других планета. Чувени дијалог између Малог принца и лисице уграђен у текст овог бајковитог романа преплетом симбола указује на универзал- 
ност космичких веза. На позив Малог принца да се поигра са лисицом, она му одговара: “Не могу да се играм са тобом. Нисам припитомљена. Шта то значи припитомити?...Ја тражим пријатеље. Шта то значи припитомити? Створити везе, најзад, одговори лисица." Везе које у животу имају великог значаја, у дијалогу између лисице и Малог принца имају сложен симболички контекст. То нису само физичке везе, то су и емотивне, мисаоне везе које се не односе само на жива бића, већ и на физички свет који добија особине живог бића. Поређење и персонификација у даљем току дијалога откривају необичан поступак писца који се манифестује на следећи начин: „Твоја коса је боје злата. Биће величанствено када ме будеш припитомио. Жито које је златно подсећа ме на тебе. И ја ћу волети шум ветра у житу."

Симбол руже која је плод дубоке привржености Малог принца лепоти и њеном мирису, рађа једну нову дужност и одговорност. „Ако човек заволи ствар, цвет, биће - човек само срцем добро види. Суштина се очима не да сагледати... Било да је у питању кућа, звезде или пустоловина, оно што чини њихову лепоту - невидљиво је... Оно што ме највише узбуђује код овог Малог уснулог принца то је његова верност једном цвету, то је слика једне руже која зрачи у њему као пламен лампе, чак и кад спава..."

Срце види, осећа, пулсира за оно што човека упућује у добро. Срце је симбол психофизичког живота, протичник, орган који даје животворну течност. И вода је, као и крв, храна организму, течност која крепи утолико више што је пустиња симбол недостатка воде, симбол беживотности.

Растанак Малог принца са предметима и стеченим пријатељима представљен је симболичко-поетском сликом: “Гледаћеш ноћу звезде. Моја је исувише мала да бих ти показао где се налази. Боље је овако. Моја звезда биће за тебе једна од звезда. Волећеш да гледаш све звезде. Све ће оне бити твоји пријатељи.“

Динамични текстови бајки захтевају богатство изражајних средстава. Дијалози између животиња различитих врста, између трава, биљака и животиња, такође, доприносе разјашњењу симболичних животних представа и потреба. Над свим тим разговорима, тугама, песмама и невољама, наднесен је човек. Као пример може послужити бајка Бранка В. Радичевића, која у симболично-поетичним сликама ниже мисли и патње дечака. До тог потока не могу доћи сви, он долази само у башту добрих дечака. Права је лепота духа и срца, као и радозналости која се под- 
стиче и храни причом, дограђивањем приче о могућој појави потока на коме ће дечак правити воденице и пустати чамчиће од хартије. Дечак путује у мислима, а то је само тренутак који га одваја од стварности.

\title{
Закључак
}

Познати нобеловац Борхес о писању и писцима каже: “Сви писци пишу једну књигу, сликари творе једну слику. Свака књига је драгоцена, свака књига је зрнце нечије биографије која је и читаочева. И када није, она је у неким енергијама, а да то и не знамо." Откривамо: симболи у бајкама су универзална енергија исказана знацима, о чему сведоче народне и посебно, ауторске бајке. У њима се састају небо и земља, вода и ватра, живот и смрт, хаос и ред. Све то уграђено је у макропростор прозе бајке с циљем откривања митских, филозофских, религиозних и језичких димензија. Из тих дубина које су, попут тамног вилајета, једна безгранична тајна, изничу цивилизације из недовољно дефинисаних простора, носећи са собом симболе свога трајања.

\author{
Stana Smiljković \\ Teacher-training faculty, Vranje
}

\section{SYMBOLIC LANGUAGE OF FAIRY-TALES}

\section{Summary}

This paper points out the function of symbols which authors use to interprete characters, their dreams and coming events. Symbols widen the text of a fairy-tale, they draw a miraculous line that the heroes follow on their way to achieve their goals. Polysemantic symbols reveal special wisdom of characters, mythological, phylosophical and religious thread in a fairy-tale. In this way fairy-tale hero's perspective is being expanded, and the character progresses and develops himself by taking part in actions and dramatic conflicts. We shall illustrate this phenomenon with the examples of fairy-tales written by the most famous Serbian and Europian authors.

Key words: symbols, language, fairy-tale, characters, contemporary, author, polysemantic, miraculousness. 